\title{
Identification Density And Hosts of Semi Parasite Species in Kahramanmaras Region of Turkey
}

\author{
Tamer Ustuner \\ (Plant Protection Department, Agriculture Faculty, University of Kahramanmaras Sutcu Imam, Turkey)
}

\begin{abstract}
This study was carried out to determine the hosts and density of mistletoe species which cause problems on the forest and fruit trees in the subregions of Kahramanmaras. According to these surveys, the ratio of existence of Arceuthobium oxycedri on the host were determined as high dense and it was 16.990 number/host for Juniperus oxycedrus subsp. oxycedrus, 15.331 for Juniperus excelsa and 14.388 for Juniperus drupacea. Also Loranthus europaeus was found dense 3.327 on Quercus cerris and 2.741 on Q. infectoria. Another semi-parasite plant, Viscum album subsp. abietis was determined as dense 9.922 number/host on Abies cilicica subsp cilicica, while it was mid dense 0.449 on Cedrus libanii. Besdies, V. album subsp. austriacum was found as high dense 14.535 on Pinus nigra subsp. pallasiana. Whereas, Viscum album ssp.album was not found on any host in Kahramanmaras.
\end{abstract}

Keywords: Arceuthobium, Loranthus, Viscum, host, pine trees and density

\section{Introduction}

Conifer trees and fruit production have an important agro forestry activities inTurkey. Many external factors affect yield and quality of the production of timber and one of the important components of these are parasite and semi-parasite plants. Miller (1982) showed that the term mistletoe was first applied to the European mistletoe (Viscum album). Viscum species include three subspecies belonging to the species of Viscum album in Turkey. This subspecies are Viscum album ssp. album, Viscum album ssp. abietis and Viscum album ssp. austriacum. Ball (1993) showed that three widely distributed subspecies of $V$. album that differ in host specificity have been recognised in Europe: $V$. album subsp. album on dicotyledonous trees, V. album subsp. abietis on Abies spp., V. album subsp. austriacum on Pinus spp. and rarely Larix spp.

Since Mistletoe species have chlorophyll, it can make photo synthesis. However it does not has a root system like the other plants. Haustorium of mistletoe penetrates to xylem of host and so it .can be nourished. Mistletoe species have flowers and seeds. The external surfaces of their seeds are sticky, so they can easily stick on tree branches and they are capable of germinate over on hosts (Hawksworth and Scharpf 1986, Hawskworth and Wiens 1996). A. oxycedri was reported in Balkan states of Slovenia, Croatia, Bosnia Herzegovina, Yugoslavia and Pakistan on Juniperus communis, J. drupacea and J. oxycedrus (Bondev and Lybenova 1984, Khaldi et al. 2000, Sarangzai et al. 2010). Species of the genera Psittacanthus, Phoradendron, and Arceuthobium cause the greatest economic and ecological impacts in the Western United States and in Mexico (Geils et al. 2002a2002b). Viscum species have spread in many regions of Europe, North Africa, Austria, Asia, China, Western Europe, southern England, Scandinavia, the Balkans, Russia, Japan and Nigeria (Frohne and Pfander 1984, Kirkup et al. 2000, Ciesla et al. 2004). No research has been carried out in Kahramanmaras region as regards this topic so far.

\section{Materials And Methods}

The material of this research is mistletoe species, fruit and forest trees. Surveys were applied in Kahramanmaras subregions (Center, Afsin, Andırın, Caglayancerit, Ekinozu, Elbistan, Göksun, Nurhak, Pazarcık and Türkoglu) on September and October of 2013-2015. This study was carried out by taking random samples from 10\% of total area. Area of forest trees according to Kahramanmaras region; area of Syrian junıper (Juniperus drupacea Labill.) 25509 ha, Crimean juniper (Juniperus excelsa Bieb.) 21771 ha, Small fruited pine (Juniperus oxycedrus L. subsp. oxycedrus) 25253 ha, Taurus fir (Abies cilicica subsp cilicica Carr) 8360 ha, Taurus cedar (Cedrus libanii) 19254.4 ha, Crimean pine [Pinus nigra Arnold. Subsp. pallasiana Holmboe.] 365263 ha, Turkey oak (Quercus cerris) 25689 ha, Aleppo oak (Quercus infectoria) 15758 ha (Anonymous 2013).Mistletoe branches were counted to using field glass for tall forest trees. As proposed by Güncan (2001), Density of mistletoe species was calculated;

Density $=\mathrm{B} / \mathrm{n}$

Where $\mathrm{B}$ is number of the individuals in the total sample, $\mathrm{n}$ is the number of sample. As suggested by Ustuner and Güncan (2002), density scale was used as follows;

This work was supported by The regional directorate of forestry of Kahramanmaras 
Density scale,

A. High dense (average more than 10 branch of mistletoe on host)

B. Dense (average 1-10 between branch of mistletoe on host)

C. Mid dense (average 0.1-1 branch of mistletoe on host)

D. Low dense (average of 0.01 to 0.1 branch of mistletoe on host)

E. Scarce (average of less than 0.01 branch of mistletoe on host)

\section{Results And Discussion}

Arceuthobium, Loranthus and Viscum species were determined as density and hosts in Kahramanmaras subregions. According to the survey, ratios of A. oxycedri were calculated on hosts as follows; high dense (16.990 number/host) on J. oxycedrus subsp. oxycedrus, (15.331) on J. excelsa and (14.388) on J. drupacea. But Loranthus europaeus was found dense (3.327) on Quercus cerris and (2.741) on Q. infectoria. In addition, V. album subsp. abietis was found out to be dense with a ratio of 9.922 number/host on A. cilicica subsp. cilicica and mid dense 0.449 number/host on Cedrus libanii; V. album subsp. austriacum high dense 14.535 number/host on Pinus nigra Subsp. pallasiana of Kahramanmaras region. Arceuthobium and Viscum species were not seen on any fruit and landscape trees in Kahramanmaras region.

The density of Arceuthobium, Loranthus and Viscum species were determined respect to Kahramanmaras subregions as follows;Center subregion; A. oxycedri was determined dense on $J$. $o$. subsp. oxycedrus, J. excelsa and J. drupacea. 2.013, 1.902 and 1.021 number/host respectively. Also $V$. album subsp. abietis was detected dense with a ratio of 1.034 number/host on A. cilicica subsp. cilicica while it was not found on $C$. libanii. V. album subsp. austriacum was found dense 2.784 number/host on $P$. $n$. subsp. pallasiana.Afsin subregion; A. oxycedri was detected high dense on $J$. o. subsp. oxycedrus, J. excelsa and J. drupacea in Afsin subregion. 24.392, 21.764 and 20.954 number/host respectively. Also L. europaeus was seen dense 1.284 on $Q$. cerris and 1.056 on $Q$. infectoria. Besides $V$. album subsp. abietis was determined dense with a ratio of 1.328 number/host on A. cilicica subsp. cilicica; V. album subsp. austriacum was seen high dense 12.875 on $P$. $n$. subsp. pallasiana.

Andırın subregion; A. oxycedri was found high dense on $J$. o. subsp. oxycedrus, J. excelsa and $J$. drupacea. 58.935, 51.654 and 50.162 number/host respectively. Besides L. europaeus was seen dense 3.158 on $Q$. cerris and 2.654 on Q. infectoria. V. album subsp. abietis was determined high dense with a ratio of 50.238 (number/host) on A. cilicica subsp. cilicica and dense 1.346 on C. libanii. V. album subsp. austriacum was found high dense 49.983 on $P$. $n$. subsp. pallasiana. Caglayancerit subregion; A. oxycedri was determined high dense on $J$. o. subsp. oxycedrus, J. excelsa and J. drupacea. $11.568,10.645$ and 10.076 number/host respectively. Furthermore L. europaeus was seen dense (4.132) on $Q$. cerris and (2.573) on $Q$. infectoria. V. album subsp. austriacum was found high dense 14.684 on $P$. $n$. subsp. pallasiana.

Ekinozu subregion; A. oxycedri was determined high dense on $J$. o. subsp. oxycedrus, J. excelsa and $J$. drupacea. 14.269, 12.873 and 10.550 number/host respectively. Also L. europaeus was seen dense (9.382) on $Q$. cerris and (7.465) on $Q$. infectoria. V. album subsp. abietis was seen mid dense with a ratio of 0.726 number/host on $C$. libanii; $V$. album subsp. austriacum was found high dense 15.842 on $P$. $n$. subsp. pallasiana.Elbistan subregion; A. oxycedri was found mid dense on J. o. subsp. oxycedrus, J. excelsa and $J$. drupacea. $0.369,0.355$ and 0.256 number/host respectively. Further L. europaeus was observed dense with a ratio of 3.750 number/host on $Q$. cerris and 2.934 on $Q$. infectoria.

Göksun subregion; A. oxycedri was determined high dense on J. o. subsp. oxycedrus, J. excelsa and $J$. drupacea. 47.219, 43.876 and 40.820 number/host respectively. Also L. europaeus was seen dense with a ratio of 5.247 number/host on $Q$. cerris, while it was seen 4.865 on $Q$. infectoria. $V$. album subsp. abietis was observed high dense with a ratio of 46.625 number/host on A. cilicica subsp. cilicica, it was detected dense 2.427 number/host on C. libanii; V. album subsp. austriacum has seen high dense 48.341 on $P$. $n$. subsp. pallasiana. Nurhak subregion; A. oxycedri has been determined high dense on J. o. subsp. oxycedrus, J. excelsa and J. drupacea. 11.138, 10.241 and 10.043 number/host respectively. Also L. europaeus was found dense with a ratio of 6.321 number/host on $Q$. cerris and 5.872 on $Q$. infectoria.

Pazarclk subregion; V. album subsp. abietis, A. oxycedri and L. europaeus have not been seen on hosts. But $V$. album subsp austriacum has been found low dense 0.024 number/host on $P$. n. subsp. pallasiana. Türkoglu subregion; V. album subsp. abietis, A. oxycedri and L. europaeus have not been seen on hosts. In addition to $V$. album subsp. austriacum has been calculated mid dense 0.826 number/host on $P$. $n$. subsp. pallasiana in Türkoglu subregion.As a result A. oxycedri was observed to be different density on J. drupacea, J. oxycedrus subsp. oxycedrus and J. excelsa; L. europaeus was found different density on $Q$. cerris and $Q$. infectoria; V. a. spp. abietis was detected to be different density on A. cilicica subsp. cilicica and on C. libanii; $V$. album subsp. austriacum was observed to be different density on $P$. $n$. subsp. pallasiana in Kahramanmaras subregions. Besides A. oxycedri and V. album subsp. austriacum was found high dense while V. a. spp. abietis and L. europaeus was found dense on hosts in Kahramanmaras region. 
A. oxycedri is widespread in Turkey, A. oxycedri usually found on J. oxycedrus and J. drupacea trees in Turkey (Miller 1982, Hawksworth and Wiens 1996). Density of Arceuthobium americanum was determined on Juniperus species, density rate; 3\%, 9\%, 18\% and 32\% respecitvely (Hawksworth and Johnson 1989). In Turkey, six taxa have been determined: V. album, V. a.subsp. austriacum, V. a. subsp. abietis, V. a. subsp. album, L. europaeus and A. oxycedri (Dutkuner, 1999). L. europaeus host selection and distribution were assessed on Northern Strandjas oak forests in Turkey ( Kumbasli et al. 2011). L. europaeus was observed on oaks, mostly on Quercus pubescens, $Q$. cerris, $Q$. robur, $Q$. petraea, $Q$. pubescens, $Q$. virgiliana and $Q$. rubra in slovakia (Hegi 1981, Eliás 1985, 2002). Zebec and Idžojtić (2006) showed that L. europaeus was found on 7 species: Quercus robur, $Q$. petraea, $Q$. cerris, $Q$. pubescens, $Q$. frainetto, $Q$. rubra and $Q$. palustris in Croatia.

$V$. album ssp. album has been determined different hosts such as was observed to be dense as (8.45) on P. communis, (7.24) on Amygdalus spp., (3.32) on P. armenica, (2.56) on P. elaeagnifolia and (2.54) on $C$. monogyna in different regions of Turkey (Davis et al. 1982, Üstüner 2003, Üstüner et al. 2015). V. album subsp. album was observed on 28 host taxa of trees and shrubs, which represents the highest diversity of host trees in a single locality in the Poland (Kolodziejek et al. 2013). But V. a. ssp. album has not been found on any hosts in regions of Kahramanmaras while it was reported in the different region of Turkey and world. V. a. ssp. abietis has mainly existed in North, Center and South part of Anatolia in Turkey (Davis et al. 1982). V. a. spp. abietis was detected to be dense (5.98) on A. cilicica in Nigde (Tüfekçi et al. 2002, Üstüner 2003).

In conclusion, The mistletoe species which were determined in different densities and hosts in Kahramanmaras region, partially similar reported by Davis et al. 1982, Miller 1982, Hawksworth and Wiens 1996, Dutkuner 1999, Tüfekci et al. 2002, Üstüner 2003, Kumbasli et al. 2011, Üstüner et al. 2015 in Turkey. At the same time Hegi (1981), Bondev and Lybenova (1984), Eliás (1985, 2002), Hawksworth and Scharpf (1986), Hawksworth and Johnson (1989); Ball (1993), Khaldi et al. (2000), Geils et al. (2002a, 2002b), Cieasla et al. (2004), Zebec and Idžojtić (2006,) Sarangzai et al. (2010) and Kolodziejek et al. (2013) were reported partial similar results in the world with the present study.

\section{Acknowledgements}

Thank you that Prof.Dr. Sibel Uygur was made diagnosis mistletoe species, from Çukurova universtiy, Also The regional directorate of forestry of Kahramanmaras.

\section{References}

[1] Anonymous 2013. The forested areas of Kahramanmaras. Republic of Turkey, General directorate of forestry, Kahramanmaras Regional directorate of forestry, Statistics branch, Kahramanmaras.

[2] Ball PW 1993. Viscum L. In flora Europaea. p. 86. Cambridge Univ. Press, Cambridge, UK

[3] Bondev IA and Lyubenova MI 1984. Materials and critical notes on the Bulgarian flora. Fitologija, 24:64-67(In Russian).

[4] Ciesla WM, Geils BW and Adams RP 2004. Hosts and geographic distribution of Arceuthobium oxycedri. United States Department of agriculture forest service, US.

[5] Davis PH, Edmondson JR, Mill RR and Tan K 1982. Flora of Turkey and the East Aegean islands. University of Edinburg. Department of Botany, 7: 547-548.

[6] Dutkuner D 1999. A study on the morphological features of Lorantaceae family within the Marmara region. Turk. J. Agric. For., 23(4): 983-989.

[7] Eliás P 1985. K výskytu imelovcovitých (Loranthaceae) na Slovensku. Zpr. Čs. Bot. Společ., Praha 20: 128-132.

[8] Eliás P 2002. Hostitel'ske dreviny imelovcovitych (Loranthaceae) na Slovensku. Bull. Slov. Bot. Spolocn., Bratislava, 24: 175-180.

[9] Frohne D and Pfander HJ 1984. Mistletoe. In a colour atlas of poisonous plants. 1st ed. Wolfe Pub., pp: 155-156, London, UK.

[10] Geils BW, Wiens D, Hawksworth FG 2002a. Phoradendron in Mexico and the United States. USDA Forest Service Gen Tech. Rep.

[11] Geils BW; Tovar JC; Moody B 2002b. Mistletoes of North American Conifers. Gen. Tech. Rep. RMRS-GTR-98. Ogden, UT: U.S. Department of Agriculture, Forest Service, Rocky Mountain Research Station. 123 p.

[12] Güncan A 2001. Weeds control principles, SelcukUniversity, Agriculture faculty publications, Konya.

[13] Hawksworth FG and Scharpf RF 1986. Spread of European mistletoe (Viscum album L.) in California, US. European J. Forest Pathology.16:1-5.

[14] Hawksworth FG and Johnson DW 1989. Biology and Management of Dwarf Mistletoe in Lodgepole Pine in The Rocky Mountains, USDA Forest Service Rocky Mountain Forest and Range Experiment Station, General Technical Report Rm-169, Colorado, 38 p.

[15] Hawksworth FG and Wiens D 1996. Dwarf mistletoes: Biology, pathology and systematics. Agric. Handb. 709. Washington DC: US Department of agriculture. 410 pp. [online] Available: http://www.rms.nau.edu/publications/ah_709.

[16] Hegi G 1981: Illustrierte Flora von Mitteleuropa, Band III, Teil 1. Verlag Paul Parey, Berlin, Hamburg, 504 pp.

[17] Khaldi A, Khouja ML, Abdelmoula K and Khouaja A 2000. The situation of Juniperus phoenicea and J. oxycedrus in Tunisia. Paper presented at the international symposium problems of juniper forests, Osh, Kyrgystan.

[18] Kolodziejek J, Patykowski J and Kolodziejek R 2013. Distribution, frequency and

[19] host patterns of European mistletoe (Viscum album subsp. album) in the major city of Lodz, Poland. Biologia 68/1: 55-64, 2013 Section Botany DOI: 10.2478/s11756-012-0128-4.

[20] Kirkup DW, Polhill RM and Wiens D 2000. Viscum in the context of its family Viscaceae and its diversity in Africa. In: Mistletoe: The Genus Viscum, ed. A. Bussing. Harwood Academic Publishers.

[21] Kumbasli M, Keten A, Beskardes V, Makineci E, Özdemir E, Yilmaz E, Zengin H, Sevgi O, Yilmaz HC and Caliskan S. 2011. Hosts and distribution of yellow mistletoe (L. europaeus Jacq. (Loranthaceae) on Northern Strandjas Oak Forests-Turkey. Scientific Research and Essays Vol. 6(14), pp. 2970-2975.

[22] Miller AG 1982. Arceuthobium Bieb. and Viscum album L. (Flora of Turkey and the East Aegean Islands), University Press, Edinburgh. 
[23] Sarangzai AM, Khan N, Wahab M and Kakar A 2010. New spread of dwarf mistletoe (Arceuthobium oxycedri) in juniper forests, Ziarat, Balochistan, Pakistan. Pakistan J. Bot. 42(6): 3709-3714.

[24] Tüfekci S, Savran A, Bagcı Y and Özkurt N 2002. Aladaglar national park flora. Ministry of forests publication, Number: 206, Page: 94. Ministry of Forests, Research Institute of Eastern Mediterranean Forestry, Tarsus.

[25] Üstüner T and Güncan A 2002. A Research on weed species which are problem, importance, biology of germination and control possibilties of them in potato fields in Nigde province. Ph. D Thesis, Department of plant protection, Selcuk University, Konya, Turkey.

[26] Üstüner T 2003. Identification and density of Viscum species in Nigde province. J. Turkish Weed Sci. 6 (2): $45-53$.

[27] Üstüner T, Düzenli S and Kitis YE 2015. Determination of infection rate of mistletoe (V. album) on hosts in Nigde province. .J. Turkish Weed Sci.:18(1-2); 5-14.

[28] Zebec M and Idžojtić M 2006. Hosts and Distribution of Yellow Mistletoe, L. europaeus Jacq. in Croatia. ladnikia 19: 41-46. 